\title{
Contemporaneous Relationship between Trading Volume and Stock Returns Volatility : Evidence from Nepalese Stock Market
}

\author{
Shivaram Shrestha ${ }^{1}$
}

\begin{abstract}
This paper examines the contemporaneous relation between trading volume and stock returns volatility for Nepalese stock market using monthly data for the period 2005 mid-July to 2017 mid-April. The study uses ordinary least square method and analyzes whether rising price leads to higher volume or vice versa. The study also investigates the association between trading volume and stock returns volatility based on monthly data of NEPSE index and examines the effects of trading volume on stock returns volatility using $\operatorname{GARCH}(1,1)$ model. The study finds positive contemporaneous relationship between trading volume and stock return volatility. The study result indicates that the relationship between trading volume and return volatility is asymmetric. The findings strongly support the hypothesis that higher trading volume is associated with an increase in stock return volatility, but offers little support to the sequential arrival hypothesis and the mixture of distribution hypothesis. Finally, the findings support the weak-form efficient market hypothesis in Nepalese stock market.
\end{abstract}

Key Words: Trading volume, Stock returns volatility, Contemporaneous relationship, $\mathrm{GARCH}$, Nepalese stock market

\section{INTRODUCTION}

Trading volume and stock return volatility are indicators of stock market activity and work as potential sources of information for the future behavior of stock market. Numerous studies have documented that high stock market volume is associated with high volatility. It has also been noted that volume tends to be higher when stock prices are increasing than when prices are falling. Pricing of securities depends on volatility of each asset. Therefore, price changes indicate the average reaction of investors to news. The arrival of new information instigates investors to revise their expectation and this is the main cause for price and return changes.

1. Mr. Shrestha is Ph.D. research scholar at the Faculty of Management, Tribhuvan University Email: shivaram.shrestha@gmail.com 
The relationship between stock returns volatility and trading volume has been investigated by many researchers since 1970, and researchers e.g. Karpoff (1987), Gallant, Rossi and Tauchen (1992), Zhao and Wang (2003), Yin (2010) have documented that trading volume and volatility have positive and contemporaneous correlation. However, some recent papers challenged these findings. Asai and Unite (2007) found negative relationship between stock returns volatility and trading volume in Phillipines stock market. Girard and Biswas (2007) found negative relationship in 27 emerging markets. Kiran (2010) could not found positive relation in Istanbul market. Amatyakul (2010) also presented the evidence showing negative correlation between volume and jumps in the S \& P 500 stock prices.

In Nepal, only a few studies have made attempts to investigate stock returns and trading volume relationship. Among them Shrestha (2011) found an asymmetric V-shaped contemporaneous relationship between positive and negative stock returns and trading volume in Nepalese stock market and Phuyal and Sharma (2013) detected significant contemporaneous relationship between return volatility and trading volume in Nepalese stock market. A few other studies have studied stock returns, return volatility and trading volume, but separately.

Trading volume and return volatility are among the most heavily studied variables in the microstructure literature of financial markets but the relationship between these variables is still under debate among the researchers. Either only the contemporaneous correlation as explained by the mixture-of-distribution (MDH) hypothesis or causal (lead- lag) relation as suggested by the sequential information arrival hypothesis (SIAH) hypothesis. The behaviors of stock return volatility and trading volume are concern to many groups of people. Traders, speculators, hedgers, and arbitrageurs alike are interested in extracting information from these variables to know how their reaction to new information and interaction can be used in predicting future prices. Policymakers and regulators are interested in knowing how changes in these variables influence the market activity and its regulation. Investors, analysts, brokers, dealers and regulators care about stock returns volatility not just because it is perceived as a measure of risk, but because they worry about "excessive" volatility in which observed fluctuations in stock prices do not appear to be accompanied by any important news about the firm, industry or market as a whole. Therefore there is a need of study to investigate contemporaneous relationship between trading volume and stock returns volatility.

The main objective of the study is to examine contemporaneous relationship between trading volume and stock return volatility in the context of Nepalese capital market using OLS regression analysis and GARCH methodology. The study uses monthly times series data sets for a period of 11 years (mid-July 2005 to mid-April 2017).

The rest of the paper is organized as follows: the next section discusses the conceptual relationship between trading volume and stock returns volatility and presents a brief survey of empirical research on this issue. The third section highlights the methodology of the present study. This is followed by discussions on the results of the study in the fourth section. Section 5 concludes the paper. 


\section{REVIEW OF LITERATURE}

There are two competing theoretical models that explain the relationship between stock returns volatility and trading volume: the mixture of distribution model $(\mathrm{MDH})$ and the sequential arrival of information model (SAIH). The MDH model was proposed by Clark (1973) and extended by Epps and Epps (1976) and Tauchen and Pitts (1983). According to the $\mathrm{MDH}$, the relationship between asset price volatility and trading volume is a function of a common latent variable, that is, the rate at which information arrives in the market. The SAIH model was proposed by Copeland $(1976,1977)$ and later extended by Jennings, Stark and Fellingham (1981) and Smirlock and Starks (1984).This hypothesis states that information dissemination occurs sequentially to investors, causing a series of intermediate equilibrium prices, and thus leading to a final informational equilibrium price when all the investors are informed.

Mixture of distribution hypothesis $(\mathrm{MDH})$ assumes that price changes follow a mixture of normal distribution with the rate of information arrival to the market as the mixing variable. In this model, trading volume is considered as a mixing variable and serves as a proxy for asset returns. Trading volume is able to measure the degree of disagreement between traders due to differences in reacting to new information as it arrives in the market. As the disagreement widens trading volume increases, suggesting a positive relationship between volume and variance of returns. The MDH suggested that stock returns and trading volume are related due to their joint dependence on underlying latent information flow variables. The more information arrives to the market (information clustering) the more stock prices tend to fluctuate. This hypothesis suggests the existence of a positive contemporaneous relationship between trading volume, return and volatility. This means that the advent of information flow into the market causes a simultaneous variation in trading volume, return and volatility. The dissemination of information is therefore simultaneous at the level of investors, so that transition to the market equilibrium is immediate.

The SIAH argued that individuals receive new information sequentially in random order and response to the information at that time, while trading volume is a positive logarithm function of number of traders and strength of new information which is the size of change in traders' demand curve. It suggests a gradual dissemination of information at the level of investors, which implies that a series of intermediate balances take place first before the completion of the final balance. According to Karpoff (1987), in the Sequential Information Arrival Hypothesis model, information is assumed to arrive asymmetrically as it is only disseminated to only one trader at a given time and that trades occur immediately after the trader receives the information. If the trader is an optimist, the information causes an upward price movement of a fixed amount, but it will cause a negative shift in the curve if the trader is a pessimist. The information arrival allows for several temporary equilibrium prices before reaching a final equilibrium price. Accordingly, in the SIAH model, the pricevolume relationship is influenced by both the previous pattern of information arrival 
and whether the next trader is an optimist or pessimist. SIAH implies that there is a positive contemporaneous, lagged and causal relations between price volatilities and trading activities. Thus, informed traders take positions and adjust their portfolios accordingly, before uninformed traders, in turn, make necessary adjustments to balance their assets. Once all investors reacted to this new information, a final equilibrium is attained. This successive reaction of traders to new information indicates that lagged values of trading volume can help predict current values of returns and volatility, and vice versa.

The following table shows the research works that support the MDH or SIAH.

\begin{tabular}{ll}
\hline MDH, Clark (1973) & SIAH, Copeland (1976) \\
\hline Epps and Epps (1976) & Jennings, Starks and Fellingham (1981) \\
Tauchen and Pitts (1983) & Smirlock and Stark (1984) \\
Harris (1986) & Gwilyn, McMillan and Speight (1999) \\
Lamoureux and Lastrapes (1990) & McMillan and Speight (2002) \\
Foster (1995) & Darrat, Rahman and Zhong (2003) \\
Andersen (1996) & Mahajan and Singh (2009) \\
Jacobs ad Onochie (1998) & Biswas and Rajib (2011) \\
Gallo and Pacini (2000) & El-Ansary and Atuea (2012) \\
Ciner (2002) & Abidin, Banchit, Lou and Niu (2013) \\
Bohl and Henke (2003) & Habibou (2016) \\
Gurgul, Majdosz and Mestel (2005) & \\
Alsubaie and Najand (2009) & \\
Pati and Rajib (2010) & \\
Celik (2013) & \\
\hline
\end{tabular}

The contemporaneous relationship between trading volume and stock return volatility was studied by several researchers. Many researcher found positive contemporaneous relation, however some researcher found negative contemporaneous relationship between such variables. Some examples of such studies are as follows.

\begin{tabular}{lllll}
\hline Author & Assets & Data period & Data interval & TV and VOL \\
\hline $\begin{array}{l}\text { Godfrey, Granger and } \\
\text { Morgenstern (1964) }\end{array}$ & Stock Market aggregates & $1959-1962$ & $\begin{array}{l}\text { Transactions, } \\
\text { daily, weekly }\end{array}$ & Positive relation \\
Ying (1966) & S\&P 500 index, NYSE, USA & $1957-1962$ & Daily & Positive relation \\
Crouch (1970) & DJIA, S\&P500, NYSE USA & $1963-1967$ & Daily, hourly & Positive relation \\
Kraus and Stoll (1972) & 402 Stocks in the NYSE & $1968-1969$ & Daily & Positive relation \\
Morgan (1976) & 17 NYSE stock & $1947-1968$ & Daily, monthly & Positive relation \\
Westerfield (1977) & 315 common stocks & $1968-1979$ & Daily & Positive relation \\
Harris (1983) & 50 common stocks & $1981-1983$ & Daily & Positive relation \\
Comiskey, Walking and & 211 common stocks & $976-1979$ & Yearly & Positive relation \\
Weeks (1984) & 50 NYSE common stocks & $1981-1983$ & Daily & Positive relation \\
Harris (1987) & S\&P 500 stock index & $1 / 1979-$ & hourly & Positive relation \\
Jain \& Joh (1988) & Americian Stock exchange & $1857-1987$ & Monthly & Positive relation \\
Schwert (1990) & A & &
\end{tabular}


44 I PYC Nepal Journal of Management, August 2017, Vol. X, No. 1

\begin{tabular}{|c|c|c|c|c|}
\hline Author & Assets & Data period & Data interval & TV and VOL \\
\hline $\begin{array}{l}\text { Bessembinder and } \\
\text { Seguin (1992) }\end{array}$ & S\&P 500 index & $1978-1989$ & Daily & Positive relation \\
\hline $\begin{array}{l}\text { Jones, Kaul and Lipson } \\
\text { (1994) }\end{array}$ & NASDAQ 835 Securities & $1986-1991$ & Daily & Positive relation \\
\hline $\begin{array}{l}\text { Moosa and Al-Loughani } \\
\text { (1995) }\end{array}$ & 4 emerging Asian Markets & $1986-1993$ & Monthly & Positive relation \\
\hline Brailsford (1996) & Australia stock Market & 1989-1993 & Daily & Positive relation \\
\hline Kim and Rhee (1997) & Tokyo Stock Exchange & 1989-1992 & Daily & No relation \\
\hline $\begin{array}{l}\text { Phylaktis, Kavussanos } \\
\text { and Manalis (1999) }\end{array}$ & Athens Stock Exchange & 1990-1996 & Daily & No relation \\
\hline $\begin{array}{l}\text { Bhattacharya, Daouk, } \\
\text { Jorgenson, and Kehr } \\
(2000)\end{array}$ & Maxican Stock Market & 1994-1996 & Daily & No relation \\
\hline $\begin{array}{l}\text { Guner and Onder } \\
\text { (2002) }\end{array}$ & Turkish stock market & & & Positive relation \\
\hline $\begin{array}{l}\text { Mestal,Gurgul and } \\
\text { Majdooz (2003) }\end{array}$ & $\begin{array}{l}31 \text { companies of Australian } \\
\text { stock Market }\end{array}$ & $2000-2003$ & Daily & Positive relation \\
\hline $\begin{array}{l}\text { Girard and Biswas } \\
(2007)\end{array}$ & \multicolumn{2}{|c|}{22 developed and 27 emerging Market } & & $\begin{array}{l}\text { Positive relation } \\
\text { in developed and } \\
\text { Negative relation } \\
\text { in emerging } \\
\text { markets }\end{array}$ \\
\hline $\begin{array}{l}\text { Deo, Srinivasan and } \\
\text { Devanadhen (2008) }\end{array}$ & 7 Asia pacific stock markets & $2004-2008$ & Daily & Positive relation \\
\hline $\begin{array}{l}\text { Alsubaie and Najand } \\
\text { (2009) }\end{array}$ & $\begin{array}{l}15 \text { Individual firms of Saudi } \\
\text { Stock market }\end{array}$ & 1993-2005 & Daily & Positive relation \\
\hline $\begin{array}{l}\text { Girard and Omran } \\
(2009)\end{array}$ & $\begin{array}{l}79 \text { companies of Cairo \& } \\
\text { Alexandria stock exchange }\end{array}$ & $1998-2005$ & Daily & Negative relation \\
\hline $\begin{array}{l}\text { Mahajan and Singh } \\
(2009)\end{array}$ & SENSEX & $1996-2006$ & Daily & Positive relation \\
\hline $\begin{array}{l}\text { Giot, Laurent and } \\
\text { Petitjean (2010) }\end{array}$ & 100 largest stock of NYSE & $1995-1999$ & Daily & Positive relation \\
\hline Hussain (2011) & DAX 30 Index & $\begin{array}{l}5 / 2004- \\
9 / 2005\end{array}$ & $\begin{array}{l}5 \text {-min } \\
\text { transaction }\end{array}$ & $\begin{array}{l}\text { Negative relation } \\
\text { with expected } \\
\text { volume and } \\
\text { positive relation } \\
\text { with unexpected } \\
\text { volume }\end{array}$ \\
\hline Louhichi (2011) & CAC 40 Index & $\begin{array}{l}\text { Jan-Dec, } \\
2007\end{array}$ & $\begin{array}{l}30 \text { min } \\
\text { transaction }\end{array}$ & Positive relation \\
\hline $\begin{array}{l}\text { Choi, Jiang, Kang and } \\
\text { Yoon (2012) }\end{array}$ & Koean stock Market & $2000-2010$ & Daily & Positive relation \\
\hline Oral (2012) & $\begin{array}{l}\text { Istanbul Stock Exchange } \\
\text { (ISE National-100) }\end{array}$ & $2005-2012$ & Daily & Positive relation \\
\hline $\begin{array}{l}\text { Ravi Chandran and } \\
\text { Bose (2012) }\end{array}$ & US stock market & $2005-2011$ & & Positive relation \\
\hline
\end{tabular}




\begin{tabular}{|c|c|c|c|c|}
\hline Author & Assets & Data period & Data interval & TV and VOL \\
\hline $\begin{array}{l}\text { Rehman, Burhan, } \\
\text { Ali-Shah and Mushtaq } \\
\text { (2012) }\end{array}$ & Karachi Stock Exchange & $2005-2010$ & Monthly & Positive relation \\
\hline Wang and Huang (2012) & Hu-Shen 300 index & $2007-2010$ & Daily & Positive relation \\
\hline $\begin{array}{l}\text { Ananzeh, Jdaitawi, and } \\
\text { Al-Jayousi (2013) }\end{array}$ & $\begin{array}{l}27 \text { stocks of Amman Stock } \\
\text { Exchange }\end{array}$ & 2002-2012 & Daily & Positive relation \\
\hline Celik (2013) & Istanbul Stock Exchange & $2005-2010$ & $\begin{array}{l}\text { Intradaily, } \\
\text { Weekly, } \\
\text { monthly }\end{array}$ & Positive relation \\
\hline Heryán (2013) & $\begin{array}{l}\text { US, China, Austria, UK, } \\
\text { Belgium, Netherland, } \\
\text { France }\end{array}$ & $2010-2013$ & Daily & Positive relation \\
\hline Naka and Oral (2013) & DJIA stock & $1990-2009$ & Daily & Positive relation \\
\hline $\begin{array}{l}\text { Meshkin, Gargaz and } \\
\text { Abbasi (2014) }\end{array}$ & Tehran Stock Exchange & $\begin{array}{l}2005 / 3- \\
2012 / 12\end{array}$ & Monthly & Positive relation \\
\hline Naik and Padhi (2014) & Indian Stock Market & $\begin{array}{l}1997 / 1 / 27- \\
2013 / 5 / 30\end{array}$ & Daily & Positive relation \\
\hline $\begin{array}{l}\text { Takaishi and Chen } \\
\text { (2016) }\end{array}$ & $\begin{array}{l}4 \text { companies of Tokyo Stock } \\
\text { Exchange }\end{array}$ & $\begin{array}{l}2006 / 6 / 3- \\
2009 / 12 / 30\end{array}$ & Daily & Positive relation \\
\hline
\end{tabular}

As a summary, a majority of the empirical studies related to the relationship between trading volume and stock returns volatility concluded the same result as shown in theoretical models. Several studies have confirmed the existence of a significant trading volume and return volatility relationship although in mixed forms and patterns. Some of the studies found negative relationship between trading volume and stock returns (e.g. (Girardand Biswas (2007), Asai and Unite (2007), Girard and Omran (2009), Kiran (2010) etc.) and some of them could not established any relationship between trading volume and stock returns (e.g., Lamoureux and Lastrapes (1990), DeMedeiros and VanDoornik (2008), Rangau, Collado and Galiay (2011)). Most of studies used daily data to show the relationship between trading volume and returns volatility. Some studies used hourly data (e.g. Lockwood and Linn (1990), Wu and Xu (2000)).Some studies used monthly data series and found positive relationship between volume and volatility (e.g. Schwert (1990), Moosa and Al-Loughani (1995), Rehman, Burhan, Ali-Shah and Mushtaq (2012) and Meshkin, Gargaz and Abbasi (2014) etc.). In nutshell, on the basis of above mentioned studies it can be stated that the significant efforts have been made at the international level to evaluate stock return volatility and trading volume, whereas in Nepal, the literature still suffering from the scarcity of studies inspecting the return volatility and trading volume relationship in Nepal.

\section{DATA AND METHODOLOGY}

This section describes the following aspects of research methodology to test the relationship between trading volume and stock returns volatility in Nepalese stock market: (i) nature and sources of data, (ii) selection of enterprises, (iii) the variables, (iv) methods of analysis, and $(v)$ the limitations of the study. 


\subsection{NATURE AND SOURCES OF DATA}

The relationship between trading volume and stock returns volatility are examined by using market turnover and stock price index data series collected from annual reports, official reports and websites of Nepal Securities Board (SEBON), and Nepalese Stock Exchange (NEPSE). The study period covers from mid-July 2005 to mid-April 2017 with 141 monthly observations of market turnover and closing price index. The monthly stock returns and trading volume are computed using monthly closing price index and monthly turnover respectively.

\subsection{VARIABLES SPECIFICATION}

The study mainly considers monthly volume series and return series to examine the relationship between trading volume and stock returns.

Trading volume: Different measures have been used to represent trading volume. Some studies have used the total number of shares traded to measure trading volume, e.g., Epps and Epps, (1976), Gallant, Rossi, and Tauchen, (1992), Hiemstra and Jones (1994) and Ying (1966). Other studies used the total number of shares traded divided by the total number of shares outstanding as a measure of trading volume, e.g., Campbell, Grossman, Wang (1993), and LeBaron (1992). Individual share volume was used in the analysis of price/volume and volatility/volume relations by Andersen (1996), Epps and Epps (1976), and Lamoureux and Lastrapes (1990, 1994). Alternatively, even the total number of trades were used by Conrad, Hameed, and Niden, (1994). James and Edmister, (1983) used the number of trading days per year as measures of trading activity.

The NEPSE provides three measures of trading volume: 1) the volume traded (the sum of the number of shares traded during the period); 2) the number of trades (the sum of trades during the period); 3) the total value traded expressed in NPR (the sum of the prices of shares traded times the number of shares traded). This study uses the total value traded as the measure of trading volume because it takes into account of the relative market value of shares. The monthly trading volume is calculated using the natural log of the ratio of a market turnover (TV) from the current month ( $t$ ) to the previous month (t-1) as:

$$
\mathrm{V}_{\mathrm{t}}=\text { monthly trading volume }=\operatorname{Ln}\left(\frac{\mathrm{TV}_{\mathrm{t}}}{\mathrm{TV}_{\mathrm{t}-1}}\right) \times 100
$$

Stock returns: The study considered monthly price index change as stock returns. A monthly price index change is calculated using the natural log of the ratio of a stock's price index $(P)$ from the current month $(t)$ to the previous month $(t-1)$ as:

$$
\mathrm{R}_{\mathrm{t}}=\text { monthly stock returns }=\operatorname{Ln}\left(\frac{\mathrm{P}_{\mathrm{t}}}{\mathrm{P}_{\mathrm{t}-1}}\right) \times 100
$$

Where, $\mathrm{P}_{\mathrm{t}}$ represents the closing price index for the period $\mathrm{t}$; $\mathrm{t}$ is the time in months. $P_{t-1}$ is the closing price index for the period of $t-1 ; \operatorname{Ln}($.$) is the natural logarithm operator.$ All returns are expressed in percentage and are not adjusted for dividends. The study also utilizes the first order difference of stock returns to maintain same order. 
Stock returns volatility: The volatility of return series at time $t$ is noted as $\mathrm{RV}_{\mathrm{t}}$. It measures in two ways, the absolute value of stock returns at time t noted as $\left|R_{t}\right|$ and the square of returns series at time t noted as $\mathrm{R}_{\mathrm{t}}^{2}$.

\subsection{METHODS OF ANALYSIS}

\subsubsection{The Models}

The Ordinary Least Square (OLS) regression equation is estimated for this study to test whether there is association between trading volume, and volatility. First, the study shows the association between the trading volumes and return volatility using model as suggested by Jain and Joh (1988), which is:

$$
\begin{aligned}
& V_{t}=\alpha_{0}+\gamma_{1}\left|R_{t}\right|+\gamma_{2} D_{t}\left|R_{t}\right|+\mu_{t} \ldots \ldots \ldots \ldots . . . \\
& V_{t}=\alpha_{0}+\gamma_{1} R_{t}^{2}+\gamma_{2} D_{t} R_{t}^{2}+\mu_{t} \ldots \ldots \ldots \ldots \ldots \ldots . . . \cdots \cdots
\end{aligned}
$$

Where, $V_{t}$ is trading volume, $\left|R_{t}\right|$ is absolute stock returns $R_{t}^{2}$ is square of stock returns, $D_{t}$ is dummy variable that equals 1 if the corresponding return $R_{t}$ is negative and 0 otherwise.

In eq. 1, $\gamma_{1}$ measures the relationship between return volatility and trading volume without taking consideration of the direction of price change. Estimation of $\gamma_{2}$ allows for asymmetric relationship. A negative $\gamma_{2}$ shows that slope or response for negative return is smaller than the response for non-negative response. Equation (2) is repetition of equation (1) using the square of the stock returns. Both equation (1) and (2) show that stock returns are the estimate measure for volatility. Thus the hypothesis of asymmetric relationship would be indicative if $\gamma_{2}$ is significantly negative.

Brailsford (1996) developed a model which relates trading volume to squared stock returns by the following regression:

$$
\begin{aligned}
& V_{t}=\alpha_{0}+\gamma_{1} R_{t}^{2}+\gamma_{1} D_{t} \times R_{t}^{2}+\alpha_{1} D M_{2}+\alpha_{2} D M_{4}+\alpha_{3} D M_{6}+\beta_{1} V_{t-1}+\beta_{2} V_{t-2}+\beta_{3} V_{t-3}+\varepsilon_{t} \ldots \ldots \ldots \ldots . . .3 \\
& V_{t}=\gamma_{1}\left|R_{t}\right|+\gamma_{1} D_{t}\left|R_{t}\right|+\beta_{1} V_{t-1}+\beta_{2} V_{t-2}+\beta_{3} V_{t-3}+\beta_{4} V_{t-4}+\alpha_{1} D M_{2}+\alpha_{2} D M_{4}+\alpha_{3} D M_{6}+\alpha_{4} D M_{3}+\varepsilon_{t} \ldots \ldots \ldots . .4
\end{aligned}
$$

Where, $D_{t}$ denotes a dummy variable that equals 1 if the corresponding return $R_{t}$ is negative and 0 otherwise and $\mathrm{DM}_{\mathrm{k}}$ denotes a monthly dummy variable that equal 1 if the corresponding month is equal to $k$ and 0 otherwise. To avoid the problem of serially correlated residuals and seasonality problem, the study includes lagged values and monthly dummy variable are added in equation 1 and 2 . The estimate of $\alpha_{1}$ parameter measures the relationship between return volatility and trading volume irrespective of the direction of the price change. The estimate of $\alpha_{2}$, however, measures the degree of asymmetry in that relationship.

\subsubsection{GARCH $(1,1)$ Model}

Generalized Autoregressive Conditional Heteroskedasticity (GARCH) model of Bollerslev (1986) was used to investigate about the relationship between trading volume and returns and volatility. The study investigates the GARCH effects in the observed data and 
examines the effects of trading volume on returns and volatility using $\operatorname{GARCH}(1,1)$ model. The model is estimated, using the maximum likelihood method, under the Generalized Error Distribution (GED) which is the distribution likely to take into account the asymmetrical and leptokurtic characteristics of financial series (Arago and Nieto, 2005). GARCH model specification allows the current conditional variance to be a function of past conditional variances, leading volatility shocks to persist in time. To test, in particular, whether the positive contemporaneous relationship between trading volume, returns and volatility exists, the following $\mathrm{GARCH}(1,1)$ model is estimated, where volume is included in the mean equation.

Mean Equation $\quad r_{t}=\alpha_{t}+\beta_{1} r_{t-1}+\beta_{2} V_{t}+\varepsilon_{t} \ldots \ldots \ldots \ldots . .5$

Variance Equation $\sigma_{t}^{2}=\omega_{0}+\omega_{1} \varepsilon_{t-1}^{2}+\omega_{2} \sigma_{t-1}^{2} \ldots \ldots \ldots \ldots \ldots 6$

Where, $\omega>0$ and $\omega_{1} \geq 0$ and

$r_{t}=$ returns of the assets at time $\mathrm{t}$

$\mu=$ average returns

$\varepsilon_{\mathrm{t}}=$ residual returns, defined as: $\varepsilon_{t}=\sigma_{t} Z_{t}$

Where, $\mathrm{z}_{\mathrm{t}}$ is standardized residual returns and $\alpha_{t}^{2}$ is conditional variance.

For GARCH $(1,1)$, the sum of $\left(\omega_{1}+\omega_{2}\right)$ parameters is a measure of the persistence of the conditional variance of returns taking values between 0 and 1 . The higher this sum approaches unity, the more persistent is the volatility shock; this phenomenon is known as volatility clustering or hysteresis. In this model, the mean equation is written as a function of constant with an error term. Since $\alpha_{t}^{2}$ is the one period ahead forecast variance based on past information, it is called the conditional variance. The conditional variance equation specified as a function of three terms:

A constant term : $\omega$

News about volatility from the previous period, measured as the lag of the squared residual from the mean equation: $\varepsilon_{\mathrm{t}-1}^{2}$ (the $\mathrm{ARCH}$ term)

Last period forecast variance: $\sigma_{\mathrm{t}-1}^{2}$ (the $\mathrm{GARCH}$ term)

\subsubsection{Unit Root Test}

Unit root test has a crucial importance in the time series analysis as the choice of the techniques and procedures for further analysis and modeling of series depends on their order of integration. Without taking into account the presence of unit root in the variables, the analysis may produce spurious results. For this purpose, the study uses the well-known Dickey-Fuller or the Augmented Dickey-Fuller (ADF) test (Dickey and Fuller, 1981), Phillips-Perron (PP) and Kwiatkowski-Phillips-Schmidt-Shin (KPSS) unit root tests. Three variants of the model are estimated: (i) without constant and time trend, (ii) including only a constant term $(\alpha)$ as the deterministic regressor and (ii) including both constant $(\alpha)$ and time trend $(t)$ terms as deterministic regressor. ADF unit root test is sensitive towards the lag length included in the regression equation. So, the lag lengths have been chosen based on Akaike Information Criterion (AIC). 


\subsection{Limitations of Study}

The results relating to contemporaneous relationship between trading volume and stock returns volatility in this study are based on regression analysis and GARCH methodology using data of listed companies. There are large number of non-listed companies contributing to the dynamics of Nepalese economy; these are not included in the study due to data problems. The study used monthly data ranging from mid-July 2005 to mid-April 2017 comprising 141 observations. Perhaps data from a longer period could have yielded a more robost result.

\section{ESTIMATION AND RESULTS}

The purpose of this section is to provide the empirical results of contemporaneous relationship between trading volume and stock returns volatility in Nepalese stock market. The analysis consist of: (i) descriptive statistics of variables, (ii) Pearson correlation analysis, (iii) unit root test, (iv) auto correlation analysis, (vi) run test, and (vii) regression analysis of contemporaneous relationship between trading volume and stock returns volatility, and (vii) GARCH methodology.

\subsection{Descriptive Statistics}

The study started investigation with same basic descriptive statistics of time series of stock returns, returns volatility and trading volume from monthly data of NEPSE index for the period of mid-July 2005 to mid-April 2017. It would provide insight into the average size and deviation from mean value of the variables under study. The descriptive statistics for the variables are shown in annex 1 . The analysis shows that the mean value of monthly stock returns and trading volume over the period is $1.23 \%$ and $3.29 \%$ with standard deviation of $7.85 \%$ and $47.61 \%$ respectively. The JarqueBera statistics of stock returns and trading volume are insignificant, which indicates that series are normally distributed. Similarly, the mean value of monthly absolute returns and squared returns are $6.0557 \%$ and $62.7336 \%$ with standard deviation of $5.12 \%$ and 98.09\% respectively. Applying Jarque-Bera test for normality, significant Jarque-Bera statistics clearly rejects the hypothesis, which implies that the pattern of monthly stock returns volatility series(absolute returns and squared returns) do not conform to normal distribution, which is the precondition for any market to be efficient in the weak form (Fama (1965), Stevenson and Bear (1970), Reddy (1997), Kamath (2008) and Mahajan and Singh (2008). Further, skewnessis a measure of symmetry. The value of skewness is near to zero in stock returns and trading volume. Kurtosis is a measure of whether the data are heavy-tailed or light-tailed relative to a normal distribution. Kurtosis, either much higher or lower, indicates extreme leptokurtic or extreme platykurtic(Parkinson, 1980). The kurtosis value of stock returns and trading volume are near to 3 which indicate series are normally distributed. Thus, monthly stock returns and trading volume series are normally distributed. But, stock returns volatility does not show normally distributed series. 


\subsection{Pearson Correlation Analysis}

The correlations between stock returns, trading volume and stock returns volatility (proxy as absolute stock returns and squared stock returns) have been presented in annex 2. The correlation result shows that correlation between stock returns, trading volume and stock returns volatility are positive and significant at 1 percent level. This is an indication that there might have a relationship between trading volume, stock returns and return volatility.

\subsection{Unit Root Test}

The time series variables- stock returns, returns volatility and trading volume- should be stationary for time series analysis. The unit root test helps to test whether the times series variables are stationary or not.

The unit root test results are shown in annex 3 . The statistics are inferior to the McKinnon critical value at $10 \%$ level. The augmented Dickey-Fuller (ADF) test indicates that the null hypothesis of unit root is rejected for the level form of stock returns and first order difference of stock returns series. The Phillips-Perron (PP) test also rejected the null hypothesis of unit root for stock return, trading volume and volatility variables as did the ADF test. Philips-Perr on test has also shown that level form of volume variables have unit root in level forms. The Kwiatkowski-Phillips-Schmidt-Shin (KPSS) test also provided same result as ADF and PP test for stock return volatility. The KPSS with constant and trend is significant for stock returns and trading volume series. This indicates trading volume and stock returns with constant and trend are non-stationary. Hence, the study concludes that the times series variables-trading volume, stock returns and volatility should be used as level form for further analysis.

\subsection{Autocorrelation Analysis}

Autocorrelation test is one of the mechanisms to identify the stochastic process in time series variables of sample firms. This test helps to determine whether time series variables are dependent on their past values. The autocorrelation and partial autocorrelation of monthly stock returns, trading volume at lag one (first-order autocorrelation) are 0.1422 and -0.2069 with Q-stat 2.8939 which is significant at $10 \%$ level of significance. Thus, the null hypothesis of autocorrelation being zero at lag one can be rejected using the Q-statistic. This indicates that the monthly stock returns and trading volume are not randomly distributed. However, autocorrelation and partial autocorrelation of stock returns from lag 2 to lag 36 , the autocorrelation coefficients are insignificant at 10 percent level. The autocorrelations of volume series show insignificant at third lag, and remaining all are significant. The squared returns are insignificant up to 36 lags.

\subsection{Run Test}

An alternative test, based on runs, has been conducted to provide evidence on the randomness of the time series variables. Its application is appealing in that, unlike the serial correlation test, it is not affected by any extreme values in the time series variables. 
The hypothesis in this test is that the successive time series variables were random. The test result is presented in annex 5 . The run test result of stock returns exhibits that the total number of runs is 50 according to test value as mean. The Z-statistic of stock return, squared return and absolute return series are negative because actual number of runs is less than expected number of runs and Z-statistic of volume series and absolute returns series are positive because the actual numbers of run (76) is higher than expected numbers of run. Furthermore, the Z-statistic and P-value of stock returns series indicate that actual runs and expected runs are significantly different. Thus this suggests that stock return series are not random; but remaining all series show insignificant result which indicates series are randomly distributed.

\subsection{Regression Analysis}

The hypothesis is that there is a positive contemporaneous relationship between trading volume and volatility in Nepalese stock market, however it is in the form of asymmetric relationship. The association between trading volume and volatility for the monthly data of NEPSE index are presented in annex 6 .

The estimation of coefficient of absolute value and squared value of stock returns, that measured the relationship between trading volume and volatility without considering the direction, is positively significant. Estimation of $\Upsilon_{2}$ that measured asymmetric relationship was also found to be significant at $1 \%$ level. Therefore, the regression result indicates that the relationship between trading volume and return volatility is asymmetric.

The coefficients $\Upsilon_{1}$, is positive and significant at $1 \%$ level, and $Y_{2}$ is negative and significant at $1 \%$ level. These findings strongly support the hypothesis that higher trading volume is associated with an increase in stock return volatility and that this relationship is more pronounced when stock price increases. Good news (increase prices) therefore induces more trading volume than bad news (declining prices), which is also consistent with the assumptions put forward by behavioral finance (Ritter, 2003) and also consistent with the findings of Medeiros and Van Doornik (2008) in the Brazilian Stock Market.

The $R^{2}$ value of both regression equations are very low due to autocorrelation of dependent variable; thus lags of dependent variable and monthly dummy variables are added to both regression equations. The coefficients of absolute stock returns and squared returns are still significantly positive with greater $R^{2}$. Hence, there is statistically significant positive relationship between trading volume and stock return volatility.

\subsection{Garch (1,1) Analysis}

The study examines the contemporaneous relationship between trading volume and stock return volatility using a GARCH $(1,1)$ model with volume included in the mean equation only. As seen in Panel A of annex 6 , trading volume coefficients are positive and significant. Therefore, there is a positive contemporaneous relationship between trading volume and stock returns. Again same model is run for squared return and absolute returns (proxy for stock return volatility) in Panel $B$ and $C$ respectively. In this case also, trading volume coefficients are positive and significant. Therefore, it can be concluded 
that there is a positive contemporaneous relationship between trading volume and stock returns volatility. For GARCH $(1,1)$, the sum of $\left(\omega_{1}+\omega_{2}\right)$ parameters is near to 1 in panel $A$, $\mathrm{B}$ and $\mathrm{C}$ model, which indicates persistent volatility shock or volatility clustering.

\section{SUMMARY \& IMPLICATIONS}

The relationship between trading volume and stock return volatility has been of interest to financial economists and analysts for long. A widely documented result is the positive contemporaneous relationship between trading volume and stock returns volatility. The two most important competing theoretical models that explained this relationship are the sequential arrival of information models and, the mixture of distribution models. The study has examined the contemporaneous relationship between trading volume and stock return volatility for Nepalese stock market using stock market index data series for the period mid-July 2005 to mid-April 2017. In particular, the study uses ADF, PP and KPSS unit root tests to determine the time series properties of trading volume, stock return and returns volatility. For contemporaneous relationship analysis, the study applied ordinary least square regression model and $\operatorname{GARCH}(1,1)$ model. The result shows positive and significant effect. It indicates that volume contributes significantly in explaining the stock return volatility. The study offers the evidence of a significant positive contemporaneous relationship between trading volume and stock returns volatility in Nepalese stock market with little support to the mixture of distribution hypothesis and support to the sequential information arrival hypothesis. The findings of the study are consistent with the evidence reported by studies on many developed and emerging stock market. This finding is contradictory to the result found by Asai and Unite (2007) for the Philippines, Girard and Omran (2009) for Egypt, and Kiran (2010) for Turkey. The results presented in this study helps to increase our understanding regarding the relationship between trading volume and stock returns in Nepalese stock market. These findings also help to explain the behaviour of returns volatility and a better understanding of market movement. It also indicated that any study of trading volume and returns volatility is necessarily relating to information flow and possibly to identify a better proxy for information flow. From investment perspective, the relationship between stock returns volatility and trading volume is of great importance to investors because trading volume reflects information about market expectations. Investors can use this knowledge on trading, speculation, forecasting and finally on hedging activities. The results are useful for regulators when they consider such measures as limits on price movements and positions. For other market participants, the results are useful since they imply that volume can be used to predict prices, lending support to technical analysis. Finally, the findings contribute to the empirical literature on Nepalese stock market by detecting positive contemporaneous relation. 


\section{REFERENCE}

Alsubaie, A., \& Najand, M. (2009). Trading volume, time-varying conditional volatility, and asymmetric volatility spillover in the Saudi stock market. Journal of Multinational Financial Management, 19(2), 139-159.

Amatyakul, P. (2010). The Relationship between trading volume and jump: Processes in financial markets. Duke Journal of Economics, 22.

Ananzeh, I., Jdaitawi, Q., \& Al-Jayousi, A. (2013). Relationship between market volatility and trading volume: Evidence from Amman stock exchange. International Journal of Business and Social Science, 4(16), 188-198.

Andersen, T. G. (1996). Return volatility and trading volume: An information flow interpretation of stochastic volatility. Journal of Finance, 51(1), 169-204.

Arago, V., \& Nieto, L. (2005). Heteroskedasticity in the returns of the main world stock exchange indices: Volume versus GARCH effects. Journal of International Financial Markets, Institutions and Money, 15, 271-284.

Asai, M., \& Unite, A. (2007). The relationship between stock return volatility and trading volume:The case of the Philippines. Manila: Soka University and De La Salle University.

Bessembinder, H., \& Seguin, P. (1992). Futures trading activity and stock price volatility. The Journal of Finance, 47, 2015-2034.

Bhattacharya, U., Daouk, H., Jorgenson, B., \& Kehr, C.-H. (2000). When an event is not an event: The curious case of an emerging market. Journal of Financial Economics, 55, 69-101.

Bollerslev, T. (1986). Generalized autoregressive conditional heteroscedasticity. Jounral of Econometrics, 31, 307-327.

Brailsford, T. J. (1996). The empirical relationship between trading volume, returns and volatility. Accounting and Finance, 35, 89-111.

Campbell, J., Grossman, S., \& Wang, J. (1993). Trading volume and serial correlation in stock returns. Quarterly Journal of Economics, 108, 905-939.

Celik, S. (2013). New evidence on the relation between trading volume and volatility. Business and Economic Research, 3(1), 176-186.

Choi, K., Jiang, Z., Kang, S., \& Yoon, S. (2012). Relationship between trading volume and asymmetric volatility in the Korean stock market. Modern Economy, 3, 584-589.

Clark, P. (1973). A subordinated stochastic process model with finite variance for speculative prices. Econometrica, 41, 135-155.

Comiskey, E.E., Walking, R.A., Weeks, M.A. (1987). Dispersion of expectations and trading volume. Journal of Business Finance \& Accounting, 14(2), 229-239.

Conrad, J., Hameed, A., \& Niden, C. (1994). Volume and auto covariance in short horizon individual security returns. The Journal of Finance, 49(4), 305-1329.

Copeland, T. (1976). A model of assets trading under the assumption of sequential information arrival. Journal of Finance, 31, 1149-1168.

Crouch, R. (1970). The volume of transactions and price changes on the New York stock exchange. Financial Analysis Journal, 26, 104-109.

Darrat, A., Rahman, S., \& Zhong, M. (2003). Intraday trading volume and return volatility of the DJIA stock: A note. Journal of Banking and Finance, 27, 2035-2043.

DeMedeiros, O., \& VanDoornik, B. (2008). The empirical relationship between stock returns, return volatility and trading volume in the Brazilian stock market. Brazilian Business Review, 5(1), 1-17.

Deo, M., Srinivasn, K., \& Devandhen, K. (2008). The empirical relationship between stock returns, trading volume and volatility: Evidence from selected Asia-Pacific stock market. European Journal of Economics, Finance and Administrative Sciences, 12, 58-68.

Dickey, D., \& Fuller, W. (1981). Likelihood ratio statistics for autoregressive time series with unit root. Econometrica, 49, 057-1072.

Epps, T., \& Epps, M. (1976). The stochastic dependence of security price changes and transaction 
volumes: Implications for mixture of distribution hypothesis. Econometrica, 44, 305-321.

Fama, E. (1965). The behavior of stock market prices. The Journal of Business, 38(1), 34-105.

Gallant, A., Rossi, P., \& Tauchen, G. (1992). Stock prices and volume. Review of Financial Studies, 5, 199-242.

Giot, P., Laurent, S., \& Petitjean, M. (2010). Trading activity, realized volatility and jumps. Journal of Empirical Finance, 17(1), 168-175.

Girard, E., \& Biswas, R. (2007). Trading volume and market volatility: Developed versus emerging stock markets. The Financial Review, 42, 429-459.

Girard, E., \& Omran, M. (2009). On the relationship between trading volume and stock price volatility in CASE. International Journal of Managerial Finance., 5(1), 110-134.

Godfrey, M., Granger, C., \& Morgenstern, O. (1964). The random walk hypothesis of stock market behavior. Kyklos, 17, 1-30.

Guner, N., \& Onder, Z. (2002). Information and volatilty: Evidence from an emerging market. Emerging Market Finance and Trade, 38, 26-46.

Gurgul, H., Majdosz, P., \& Mestel, R. (2005). Joint dynamics of prices and trading volume on the polish stock market. Managing Global Transitions, 3, 139-156.

Harris, L. (1983, May). The joint distribution of speculative prices and of daily trading volume. Working paper. University of Southern CA.

Harris, L. (1987). Transaction data tests of the mixture of distributions hypothesis. Journal of Financial and Quantitative Analysis, 22, 127-141.

Heryán, T. (2013). Stock prices volatility and trading volume: Evidence from selected world financial companies' shares. 117-125.

Hiemstra, C., \& Jones, J. (1994). Testing for linear and nonlinear Granger causality in the stock price-volume relation. Journal of Finance, 49, 1693-1694.

Hussain, S. (2011). The intraday behaviour of bid-ask spreads, trading volume and return volatility: evidence from DAX30. International Journal of Economics and Finance, 3(1), 23-34.

Jain, P., \& Joh, G. (1988). The dependence between hourly prices and trading volume. Journal of Financial and Quantitative Analysis, 23, 269-283.

James, C., \& Edmister, R. (1983). The relation between common stock returns trading activities and market value. Journal of Finance, 38, 1075-1086.

Jones, C., Kaul, G., \& Lipson, M. (1994). Transactions, volume, and volatility. The Review of Financial Studies, 7, 631-651.

Kamath, R. (2008). The price-volume relationship in the Chilean stock market. International Business \& Economics Research Journal, 7(10), 7-14.

Karpoff, J. (1987). The relation between price changes and trading volume: A survey. Journal of Financial and Quantitative Analysis, 22, 109-126.

Kim, K., \& Rhee, S. (1997). Price limit performance: Evidence from the Tokyo stock exchange. The Journal of Finance, 52(2), 885-901.

Kiran, B. (2010). Trade volume and return volatility in Istanbul stock exchange. Dogus University Dergisi, 11(1), 98-108.

Kraus, A., \& Stoll, H. (1972). Parallel trading by institutional investors. Journal of Financial and Quantitative Analysis, 7, 2107-2138.

Lamoureux, C., \& Lastrapes, W. (1994). Endogenous trading volume and momentum in stock return volatility. Journal of Business and Economic Statistics, 12(2), 253-260.

Lamourex, C., \& Lastrapes, W. (1990). Heteroskedasticity in stock return data:Volume versus GARCH effects. The Journal of Finance, 45(1), 21-29.

LeBaron, B. (1992). Some relations between volatility and serial correlation in stock market returns. Journal of Business, 65, 199-219.

Lockwood, L.J. \& Linn, S.C. (1990). An Examination of stock market return volatility during overnight and intraday periods, 1964-1989. The Journal of Finance, 45(2), 591-601.

Louhichi, W. (2011). What drives the volume-volatility relationship on Euronext Paris? International Review of Financial Analysis, 20(4), 200-206. 
Mahajan, S., \& Singh, B. (2008). Trading volume and return volatility dynamics in Indian stock market. ICFAI Journal of Applied Finance, 14(2), 53-73.

Mahajan, S., \& Singh, B. (2009). The empirical investigation of relationship between return, volume, and volatility dynamics in Indian stock market. Eurasian Journal of Business and Economics, 2, 113-137.

Meshkin, S., Gargaz, M., \& Abbasi, E. (2014). Investigation of the relationship between trading volume, volatility and stock return in Tehran stock exchange. Journal of Applied Science and Agriculture, 9(9), 145-153.

Mestal, R., Gurgul, H., \& Majdooz, P. (2003). The empirical relationship between stock returns, return volatility and trading volume on the Austrian stock market. Retrieved from www. charttricks.com/Resources/Articles

Mohamad, S., \& Nassir, M. (1995). Price changes and trading volume relationship: Some preliminary evidence from the Kuala Lumpur stock exchange. Pertanika Journal of Social Science and Humanities, 3, 147-154.

Moosa, I. A., \& Al - Loughani, N. E. (1995). Testing the price - volume relation in emerging Asian stock markets. Journal of Asian Economics, 6, 407-422.

Morgan, I. (1976). Stock prices and heterroskedasticity. Journal of Business, 49, 496-508.

Naik, P., \& Padhi, P. (2014). Equity trading volume and its relationship with market volatility: Evidence from Indian equity market. Journal of Asian Business Strategy, 108-124.

Naka, A., \& Oral, E. (2013). Stock return volatility and trading volume relationships captured with stable paretian GARCH and threshold GARCH models. Journal of Business \& Economic Research, 11(1), 47-52.

Nowbutsing, B., \& Naregadu, S. (2009). Returns, trading volume and volatility in the stock market of Mauritius. African Journal of Accounting, Economics, Finance and Banking Research, 5(5), 1-36.

Oral, E. (2012). An empirical analysis of trading volume and return volatility relationship on Istanbul stock exchange national -100 Index. Journal of Applied Finance \& Banking, 2(5), 149-158.

Otavio, R., \& Bernardus, F. (2006). The empirical relationship between stock returns, return volatility and trading volume in the Brazilian Stock Market.

Parkinson, M. (1980). The extreme value method for estimating the variance of the rate of return. Journal of Business, 53, 61-65.

Phuyal, N., \& Sharma, N. (2013). Stocks returns, trading volume and volatility at the Nepalese stock market. SEBON Journal, 6, 1-12.

Phylaktis, K., Kavussanos, M., \& Manalis, G. (1999). Price limits and stock market volatility in the Athens stock exchange. European Financial Management, 5(1), 69-84.

Rangau, L., Collado, F., \& Galiay, U. (2011). The dynamics of the volatility - trading volume relationship: New evidence from developed and emerging markets. Economics Bulletin, 31(3), 2569-2583.

Ravichandran, K., \& Bose, S. (2012). Relationship between stock return and trading volume. Research Journal of Business Management, 6(1), 30-39.

Reddy, S. (1997). Efficiency of Indian stock markets: An empirical analysis of weak-form EMH of the BSE. UTI Indian Capital Market Conference, 91-115.

Rehman, A., Burhan, M., Ali-Shah, S., \& Mushtaq, R. (2012). The empirical relationship between risk-return and trading volume in Karachi stock exchange. Journal of Risk and Diversification, 4, 36-43.

Richardson, Sefcik, \& Thompson. (1987). A test of dividend irrelevance using volume reaction to a change in Dividend Policy. Journal of Financial Economics, 17(2), 313-333.

Schwert, G. (1990). Why does stock market volatility change over time? The Journal of Finance, 44(5), 1115-1153.

Shrestha, S. (2011). Stock returns and trading volume in Nepal. SEBON Journal, 5, 79-95.

Smirlock, K., \& Starks, L. (1985). A further examination of stock price changes and transaction volume. Journal of Financial Research, 8, 217-225. 
Stevenson, A., \& Bear, M. (1970). Commodity futures: Trends or random walks? The Journal of Finance, 25(1), 65-81.

Takaishi, T., \& Chen, T. T. (2016). The relationship between trading volumes, number of transactions, and stock volatility in GARCH models. Journal of Physics, 1-4.

Tauchen, G., \& Pitts, M. (1983). The price variability-volume relationship on speculative markets. Econometrica, 51, 31-41.

Wang, T., \& Haung, Z. (2012). The relationship between volatility and trading volume in the Chinese stock market: A volatility decomposition perspective. Annals of Economics and Finance, 13(1), 211-236.

Westerfield, R. (1977). The distribution of common stock price changes: An application of Transactions time and subordinated stochastic models. Journal of Financial and Quantitative Analysis, 12, 743-793.

Wu, C., \& Xu, X. (2000). Return volatility, trading imbalance and the information content of volume. Review of Quantitative Finance and Accounting, 14, 131-153.

Yin, W. (2010). An empirical research on China's stock market's volume-volatility relationship. World Economic Outlook, 3, 66-79.

Ying, C. (1966). Stock market prices and volumes of sales. Econometrica, 34, 676-685.

Zhao, L., \& Wang, Y. (2003). Hushen stock markets' volume, Return and volatility correlations: Evidence from empirical data analysis. Economic Science, 2, 57-67.

Zolotoy, L., \& Melenberg, B. (2007). Trading volume, volatility and return dynamics: Individual and cross market analysis. Retrieved from http://ssrn.com/abstract=1032193 


\section{ANNEX 1: DESCRIPTIVE STATISTICS}

The dataforthistable are collected and compiled from the NEPSE index at NepalStockExchange Limited for the period 2005 mid-July to 2017 mid-April with 141 monthly data. The table contained stock returns, trading volume and returns volatility series. The monthly trading volume is calculated by natural log of current monthly market turnover divided by lagged monthly market turnover, i.e. monthly trading volume $\left(V_{t}\right)=\operatorname{Ln}\left(\frac{T_{\text {Turasaver }}}{T_{u r m u r r}-1}\right) \times 100$. The monthly stock returns are calculated by natural log of current closing stock price of current month divided by one month lagged closing stock price, i.e. monthly Stock returns $\left(\mathrm{R}_{\mathrm{t}}\right)=\ln \left(\frac{P_{t}}{t_{t-1}}\right) \times 100$. The volatility is measured by the absolute value of returns at time $\mathrm{t}$ noted as $\left|R_{t}\right|$ or the square of returns series at time $t$ noted as $R_{t}^{2}$. In the table, $N$ represents number of observations and mean, maximum and minimum for average, maximum and minimum returns respectively for the period. SD stands for standard deviation of the returns. SK is a measure of skewness and KURT represents kurtosis. The Jarque-Bera (JB) test of normality is the test of the joint hypothesis that SK and KURT are 0 and 3, respectively. In that case, the value of the $\mathrm{JB}$ statistic is expected to be zero. JB is defined as $\mathrm{JB}=n\left[\frac{S^{2}}{6}+\frac{(k-3)^{2}}{24}\right]$. Any $p$-value less than 0.05 indicate that the distribution is not normal. The JB - statistic with ${ }^{* * *},{ }^{* *}$ and ${ }^{*}$ indicates that the distribution is significantly different from normal distribution at $1 \%, 5 \%$ and $10 \%$ level of significant respectively.

\begin{tabular}{cccccccccc}
\hline VAR & Mean & Median & MAX & MIN & SD & Skewness & Kurtosis Jarque-Bera & N \\
\hline $\mathrm{R}_{\mathrm{t}}$ & 1.2376 & 1.2233 & 22.4967 & -16.3308 & 7.8512 & 0.2919 & 3.2658 & 2.4006 & 140 \\
$\mathrm{~V}_{\mathrm{t}}$ & 3.2977 & 5.8557 & 128.5746 & -132.3495 & 47.6192 & -0.0411 & 3.1644 & 0.1971 & 140 \\
$\left|\mathrm{R}_{\mathrm{t}}\right|$ & 6.0557 & 4.3865 & 22.4967 & 0.0407 & 5.1233 & 1.1897 & 3.7928 & $36.6949^{* * *}$ & 140 \\
$\mathrm{R}_{\mathrm{t}}^{2}$ & 62.7336 & 19.2424 & 506.1033 & 0.0016 & 98.0962 & 2.3473 & 8.4405 & $301.2383^{\star * *}$ & 140 \\
\hline
\end{tabular}

\section{ANNEX 2: PEARSON CORRELATION MATRIX}

The table consists Pearson correlation matrix between trading volume series $\left(\mathrm{V}_{\mathrm{t}}\right)$, stock returns series $\left(\mathrm{R}_{\mathrm{t}}\right)$, absolute stock returns series $\left(\left|\mathrm{R}_{\mathrm{t}}\right|\right)$, and square return series $\left(\mathrm{R}_{\mathrm{t}}^{2}\right)$. P-values are in the parentheses. An ${ }^{*},{ }^{* *}$ and ${ }^{* * *}$ denotes statistical significance at the 10 percent, 5 per cent 1 percent level respectively.

\begin{tabular}{rccc}
\hline & $\mathrm{V}_{\mathrm{t}}$ & $\left|\mathrm{R}_{\mathrm{t}}\right|$ & $\mathrm{R}_{\mathrm{t}}^{2}$ \\
\hline $\mathrm{R}_{\mathrm{t}}$ & $0.3557^{* * *}$ & $0.2879^{* * *}$ & $0.3809^{* * *}$ \\
$\mathrm{~V}_{\mathrm{t}}$ & 1 & $0.3001^{* * *}$ & $0.3109^{* * *}$ \\
$\left|\mathrm{R}_{\mathrm{t}}\right|$ & & 1 & $0.9498^{* * *}$ \\
\hline
\end{tabular}

\section{ANNEX 3: UNIT ROOT TEST}

This table reports the results of the ADF test, PP test and KPSS test for unit roots. The lag length ( $\mathrm{p}$ ) is chosen based on AIC. The empirical model; $\Delta Y_{t}=\mu+\delta Y_{t-1}+\sum_{i=1}^{m} \alpha_{j} \Delta Y_{t-i}+\gamma t+\varepsilon_{t}$ where $\Delta Y_{t}$ is the first difference of the time series variable and $i$ is the lag order of the auto regressive process. A constant $\mu$ and the coefficient on a time trend $\gamma$ are also incorporated in the model to 
58 I PYC Nepal Journal of Management, August 2017, Vol. X, No. 1

account for the different possibilities of the unit root process. If $\mu=0$ and $\gamma=0$, it corresponds to a random walk model and if only $\gamma=0$, it equals to modeling a random walk with drift. The ADF critical value for t-statistics at 5 per cent ( 1 per cent) level for the model with the constant is $-2.88(-3.48)$ respectively.

\begin{tabular}{|c|c|c|c|c|c|c|c|}
\hline \multirow[b]{2}{*}{ VAR } & \multirow[b]{2}{*}{ lags } & \multicolumn{3}{|c|}{ At Level } & \multicolumn{3}{|c|}{ At first difference } \\
\hline & & Constant & $\begin{array}{c}\text { Constant \& } \\
\text { Trend }\end{array}$ & None & Constant & $\begin{array}{c}\text { Constant } \\
\text { Trend }\end{array}$ & None \\
\hline
\end{tabular}

1. ADF test $\Delta Y_{t}=\alpha_{0}+\gamma_{1} y_{t-1}+\alpha_{2} t+\sum_{i=1}^{p} \beta_{i} \Delta y_{t-1}+\varepsilon_{t}$

\begin{tabular}{|c|c|c|c|c|c|c|c|}
\hline$R_{t}$ & 0 & $-9.7901^{* \star \star}$ & $-9.762^{\star \star \star}$ & $-9.5964^{\star \star \star}$ & $-6.6304^{* * *}$ & $-6.5998^{\star \star \star}$ & $-6.6605^{\star \star *}$ \\
\hline$V_{t}$ & 2 & $-8.4965^{\star \star \star}$ & $-8.4579^{* \star *}$ & $-8.2857^{\star \star *}$ & $-6.9067^{* * *}$ & $-6.8771^{* \star *}$ & $-6.9424^{* \star *}$ \\
\hline$R$ & 0 & $-6.3311^{* * *}$ & $-6.3051^{\star \star \star}$ & $-0.7046 \mathrm{n} 0$ & $-8.0709^{\star * *}$ & $-8.0206^{\star \star *}$ & $-8.0835^{\star * *}$ \\
\hline $\mathrm{R}^{2}$ & 0 & $-10.4253^{* * *}$ & $-10.3712^{* * \star}$ & $-3.0978^{* * *}$ & $-7.5332^{* * *}$ & $-7.4875^{\star * *}$ & $-7.5443^{\star * *}$ \\
\hline
\end{tabular}

2. PP test $\Delta Y_{t-1}=\alpha_{0}+\gamma_{1} y_{t-1}+\alpha_{2} t+\varepsilon_{t}$

\begin{tabular}{|c|c|c|c|c|c|}
\hline .8 & 9.7 & -9.6 & -38 & -38 & -39 \\
\hline & 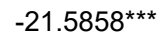 & 5 & -59 & 59 & \\
\hline 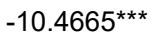 & -10.425 & $-5.805^{\star * *}$ & $-77.8055^{\star \star \star *}$ & $-83.6214^{\star \star *}$ & -59 \\
\hline 0.4 & $-10.3636^{* * *}$ & $-8.8891^{* * *}$ & $-41.3527^{* * *}$ & $-42.322^{* * *}$ & -40.5358 \\
\hline
\end{tabular}

3. KPSS test $\quad y_{t}=\alpha_{0}+\alpha_{1} t+\mu_{t}+\varepsilon_{t}$

$\begin{array}{lccc}0.1903 & 0.1613^{\star *} & 0.1177 & 0.0689 \\ 0.2737 & 0.2616^{\star \star *} & 0.1779 & 0.1479^{\star *} \\ 0.0787 & 0.0768 & 0.2795 & 0.201^{\star *} \\ 0.0642 & 0.0669 & 0.2787 & 0.1685^{\star *}\end{array}$




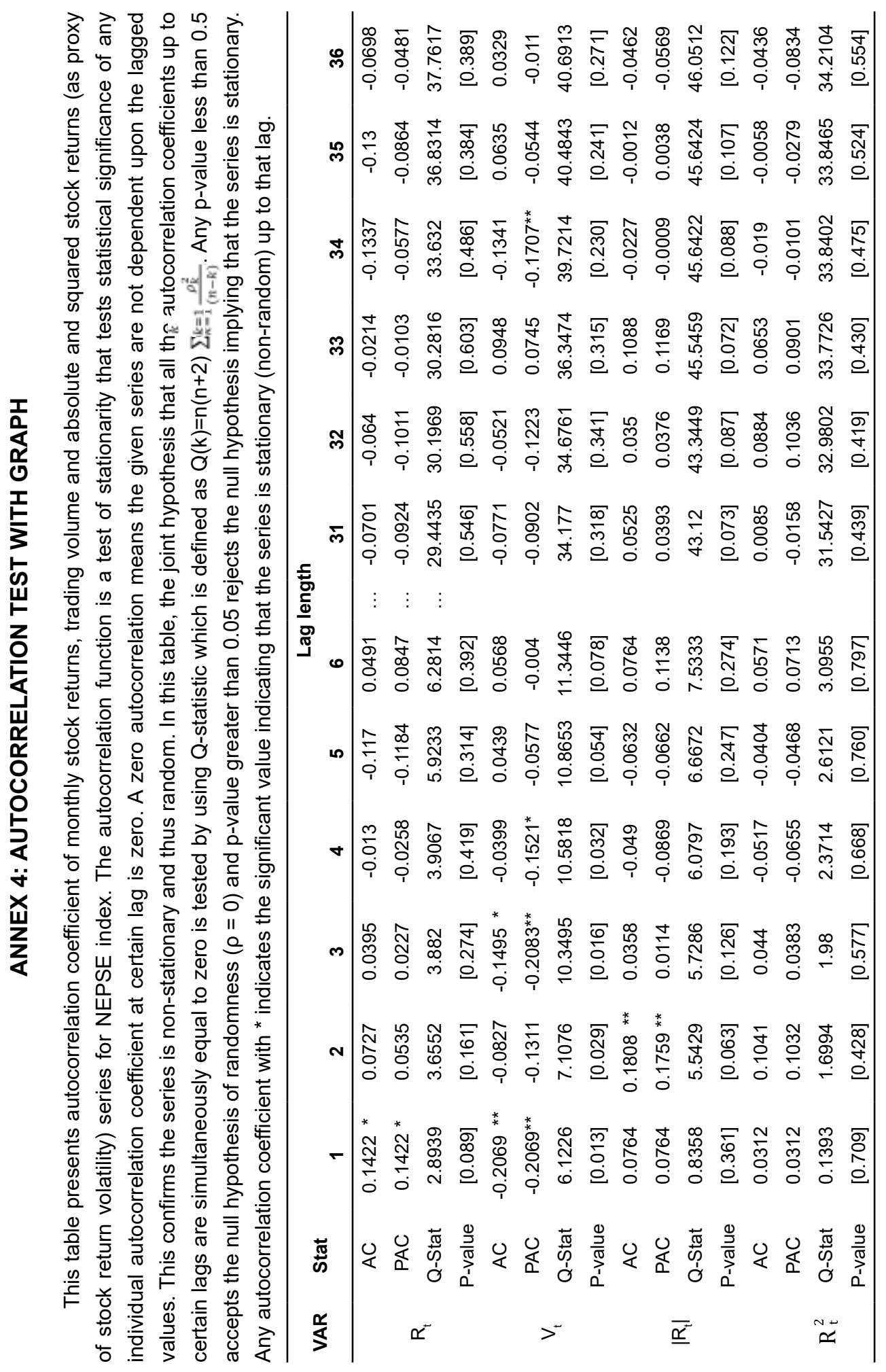



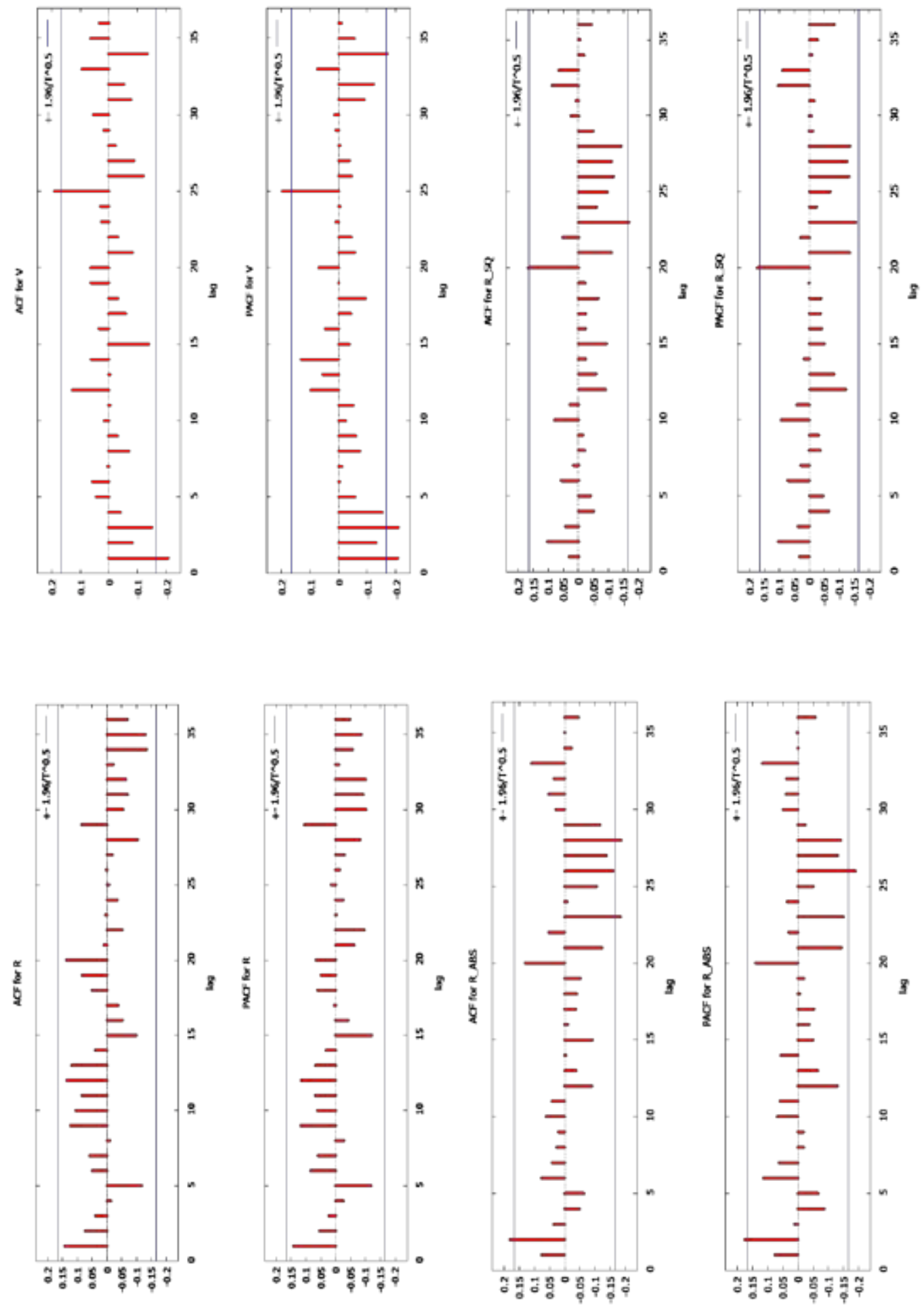


\section{ANNEX 5: RUN TEST}

This table lists statistics associated with the runs test of monthly stock returns, trading volume, absolute and squared stock returns (as proxy of volatility). Runs test, being a non-parametric test, is a procedure that examines consecutive occurrence of a variable. This variable has only two categories. The runs test classifies values of the variable as being above or below the mean, median or mode (test value). The test employs the total number of runs in the transformed data. Large significance values ( $p$-value $>0.05$ ) indicate the data are randomly ordered. ' $R$ ' for observed number of runs. Any Z-value with * indicates the significant difference between actual number of runs and observed number of run indicating that the series is not random.

\begin{tabular}{cccccccccc}
\hline & \multicolumn{3}{c}{ Mean } & \multicolumn{3}{c}{ Median } & \multicolumn{3}{c}{ Mode } \\
Var & Value & $\mathbf{R}$ & Z-Stat & Value & $\mathbf{R}$ & Z-Stat & Value & R & Z-Stat \\
\hline 1.2376 & 50 & $-3.562^{* * *}$ & 1.2233 & 50 & $-3.562^{* * *}$ & -3.1225 & 43 & $-2.873^{* * *}$ \\
3.2977 & 76 & 0.942 & 5.8557 & 76 & 1.187 & -128.57 & 3 & 0.120 \\
6.0557 & 64 & -0.338 & 4.3865 & 76 & 0.848 & 16.3308 & 16 & -1.33 \\
62.9391 & 50 & -0.998 & 19.2424 & 76 & 0.848 & 9.7501 & 58 & -0.793 \\
\hline
\end{tabular}

\section{ANNEX 6: REGRESSION ANALYSIS}

\section{Regression for relationship between trading volume and volatility}

The table provides the coefficient estimates from regression of relationship between trading volume and return volatility. Panel $A, B, C$ andt $D$ presents the result for volume related with absolute stock returns, volume related with square of stock returns, product of dummy and square of stock returns and volume related with stock returns volatility with lags and monthly dummy variables respectively of monthly data of NEPSE index over the period of 2005 Mid-July to 2017 Mid-April with 141 observations. In Panel A, $V_{t}=\alpha_{0}+\gamma_{1}\left|R_{t}\right|+\gamma_{2} D_{t}\left|R_{t}\right|+\mu_{t}$, where, $\left|R_{t}\right|$ is absolute value of stock returns at day $t$. and $D_{t}$ is dummy variable that equals 1 if the corresponding return $R_{t}$ is negative and 0 otherwise. and $\mu_{t}$ a random error term. In Panel $B, V_{t}=\alpha_{0}+\gamma_{1} R_{t}^{2}+\gamma_{2} D_{t} R_{t}^{2}+\mu_{t}$ where, $\mathrm{R}_{\mathrm{t}}^{2}$ is square of the stock returns and Panel $\mathrm{C}, \mathrm{V}_{\mathrm{t}}=\alpha_{0}+\gamma_{1} \mathrm{R}_{\mathrm{t}}^{2}+\gamma_{1} \mathrm{D}_{\mathrm{t}} \times \mathrm{R}_{\mathrm{t}}^{2}+\alpha_{1} \mathrm{DM}_{2}+\alpha_{2} \mathrm{DM}_{4}+\alpha_{3} \mathrm{DM}_{6}$ $+\beta_{1} \mathrm{~V}_{\mathrm{t}-1}+\beta_{2} \mathrm{~V}_{\mathrm{t}-2}+\beta_{3} \mathrm{~V}_{\mathrm{t}-3}+\varepsilon_{\mathrm{t}}$ and Panel $\mathrm{D}, \mathrm{V}_{\mathrm{t}}=\gamma_{1}\left|\mathrm{R}_{\mathrm{t}}\right|+\gamma_{1} \mathrm{D}_{\mathrm{t}}\left|\mathrm{R}_{\mathrm{t}}\right|+\beta_{1} \mathrm{~V}_{\mathrm{t}-1}+\beta_{2} \mathrm{~V}_{\mathrm{t}-2}+\beta_{3} \mathrm{~V}_{\mathrm{t}-3}+\beta_{4} \mathrm{~V}_{\mathrm{t}-4}+\alpha_{1} \mathrm{DM}_{2}+\alpha_{2}$ $\mathrm{DM}_{4}+\alpha_{3} \mathrm{DM}_{6}+\alpha_{4} \mathrm{DM}_{8}+\varepsilon_{\mathrm{t}}$ where $\mathrm{V}_{\mathrm{t}-\mathrm{k}}$ is $\mathrm{k}$ period lagged value of trading volume, $\mathrm{DM}_{\mathrm{n}}$ is $\mathrm{n}^{\text {th }}$ month dummy variables.

\section{PANEL A}

\begin{tabular}{cccccc}
\hline VAR & Coefficient & F-Value & $\mathbf{R}^{2}$ & AIC & DW \\
\hline$\alpha_{0}$ & $-10.4216^{*}$ & & & & \\
$\gamma_{1}$ & $3.7225^{\star * *}$ & $9.8444^{* * *}$ & $10.85 \%$ & 1530.1062 & 2.4292 \\
$\gamma_{2}$ & $-3.6625^{\star * *}$ & & & & \\
\hline
\end{tabular}


62 I PYC Nepal Journal of Management, August 2017, Vol. X, No. 1

PANEL B

\begin{tabular}{cccccc}
\hline VAR & Coefficient & F-Value & $\mathbf{R}^{2}$ & AIC & DW \\
\hline$\alpha_{0}$ & -3.1048 & & & & \\
$\gamma_{1}$ & $0.1772^{* * *}$ & $7.1745^{\star * *}$ & $8.48 \%$ & 1533.7776 & 2.3846 \\
$\gamma_{2}$ & $-0.2174^{* * *}$ & & & & \\
\hline
\end{tabular}

PANEL C

\begin{tabular}{cccccc}
\hline VAR & Coefficient & F-Value & $\mathbf{R}^{2}$ & AIC & DW \\
\hline$\alpha_{0}$ & $-9.9864^{*}$ & & & & \\
$\gamma_{1}$ & $3.9585^{* * *}$ & & & \\
$\gamma_{2}$ & $-4.3488^{* * *}$ & & & \\
$\alpha_{1}$ & $32.1871^{* *}$ & & & \\
$\alpha_{2}$ & $33.7402^{* * *}$ & $14.0358^{* * *}$ & $44.00 \%$ & & \\
$\alpha_{3}$ & $-33.1018^{\star * *}$ & & & & \\
$\beta_{1}$ & $-0.4148^{* * *}$ & & & \\
$\beta_{2}$ & $-0.2356^{* * *}$ & & & \\
$\beta_{3}$ & $-0.2534^{* * *}$ & & & \\
\hline
\end{tabular}

PANEL D

\begin{tabular}{cccccc}
\hline VAR & Coefficient & F-Value & $\mathbf{R}^{2}$ & AIC & DW \\
\hline$\gamma_{1}$ & $3.2182^{* * *}$ & & & & \\
$\gamma_{2}$ & $-4.5567^{* * *}$ & & & \\
$\alpha_{1}$ & $26.15^{* * *}$ & & & \\
$\alpha_{2}$ & $27.1296^{* * *}$ & & & \\
$\alpha_{3}$ & $-37.78^{* * *}$ & $13.8418^{* * *}$ & $43.46 \%$ & & \\
$\beta_{1}$ & $-0.4301^{* * *}$ & & & & \\
$\beta_{2}$ & $-0.2357^{* * *}$ & & & \\
$\beta_{3}$ & $-0.2724^{* * *}$ & & & \\
$\beta_{4}$ & -0.0804 & & & \\
\hline
\end{tabular}




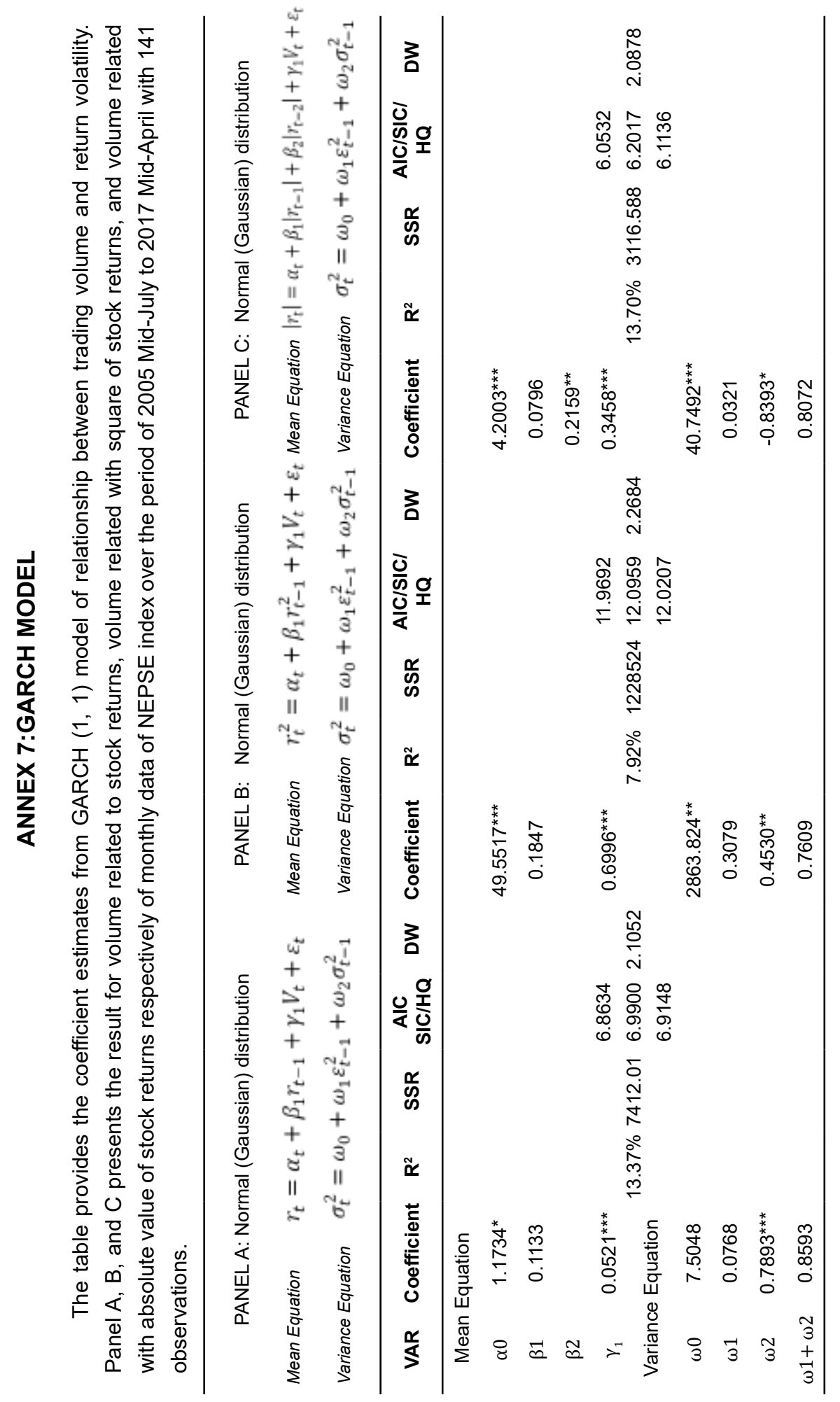

